Int. J. Electrochem. Sci., 14 (2019) 3350 - 3362

International Journal of

ELECTROCHEMICAL

SCIENCE

WWW.electrochemsci.org

\title{
Potentiometeric Study of New Schiff Base Complexes Bearing Morpholine in Ethanol-water Medium with some Metal Ions
}

\author{
Badriah. S. Al-Farhan, ${ }^{1,}$, Gamal. A. Gouda ${ }^{2}$, O. A. Farghaly ${ }^{2}$ and A.K. EL Khalafawy ${ }^{1}$ \\ ${ }^{1}$ Chemistry Department, Faculty of Girls for Science, King Khalid University, Abha, King Saudi \\ Arabia, KSA. \\ ${ }^{2}$ Chemistry Department, Faculty of Science, Al-Azhar University, Assiut Branch, 71524, Assiut, \\ Egypt. \\ *E-mail: shahd_bb@hotmail.com
}

doi: $10.20964 / 2019.04 .38$

Received: 14 December 2018 / Accepted: 24 January 2019 / Published: 10 March 2019

Acid dissociation constants of 2-[(4-morpholinobenzylidene)amino]phenol (HL) and the equilibrium constants of their metal complexes with $\mathrm{Cu}^{2+}, \mathrm{Zn}^{2+}, \mathrm{Sr}^{2+}, \mathrm{Cd}^{2+}, \mathrm{Ba}^{2+}$ and $\mathrm{Hg}^{2+}$ ions were investigated using a $\mathrm{pH}$ metric titration technique in $40 \%(\mathrm{v} / \mathrm{v})$ ethanol-water medium and $\mu=0.5 \mathrm{M} \mathrm{NaClO}_{4}$. The dissociation constants $\left(\mathrm{pK}_{\mathrm{a}}\right)$ of HL ligand and the stability constants of the respective complexes (log $\mathrm{K}_{\mathrm{i}}$ ) were calculated at 298,308 and $318 \mathrm{~K}$. The values of dissociation constants $\left(\mathrm{pK}^{\mathrm{OH}}\right.$ and $\left.\mathrm{pK}^{\mathrm{NH}}\right)$ of monoprotic HL were found as 10.36 and 2.95, respectively. The formation constants of the complexes increase in the arrangement of $\mathrm{Sr}^{2+}<\mathrm{Zn}^{2+}<\mathrm{Cd}^{2+}<\mathrm{Hg}^{2+}<\mathrm{Ba}^{2+}<\mathrm{Cu}^{2+}$ ions. The thermodynamic functions for the protonation and the deprotonation process of $\mathrm{HL}$ and their metal complex equilibria are derived and discussed. The formation metal complexes of $\mathrm{Cu}^{2+}, \mathrm{Zn}^{2+}, \mathrm{Sr}^{2+}, \mathrm{Cd}^{2+}, \mathrm{Ba}^{2+}$ and $\mathrm{Hg}^{2+} \mathrm{h}$ as been found to be endothermic and spontaneous processed. Furthermore, the geometric parameters of the metal-HL complexes were studied according to the density functional theory (DFT) method.

Keywords: pH-Metric, stability constants, thermodynamic, theoretical studies.

\section{$\underline{\text { FULL TEXT }}$}

(C) 2019 The Authors. Published by ESG (www.electrochemsci.org). This article is an open access article distributed under the terms and conditions of the Creative Commons Attribution license (http://creativecommons.org/licenses/by/4.0/). 